https://doi.org/10.18485/iipe_euchanges.2021.ch19

\title{
HOAXES AND FAKE NEWS OF THE NEO-FASCISTS IN SLOVAKIA: COMMUNICATION STRATEGIES, REFLECTIONS, IMPACT ON INTERNAL AND SECURITY POLITICS
}

\begin{abstract}
Anton HRUBOŇ${ }^{1}$
Abstract: This contribution analyses profiling European-wide and local specific features of the neo-fascist propaganda strategies in Slovakia in the last decade, with special attention to the role of hoaxes and fake news, which, at the times of massive internetization and growing impact of the cyberspace, essentially help their producers to spread the ideas of 'alternative world' and 'alternative truths' to their addressees and offer a set of simple solutions for complicated global problems. The article discusses the hypothesis that the neo-fascist parties/movements are currently not a peril for the democratic system as such since they do not possess enough political power to overthrow it. Their real danger, however, lies in the fact that the hoaxes and fake news produced by those organizations, as core elements of their propaganda, are being adopted by many 'traditional' and governmental parties, which may seriously affect the public discourse, the attitude of the state authorities towards nonmilitary security threats (including political extremism) and, eventually, radicalize the political regime's nature itself via 'cultural fascistization' of political language and gradual 'normalization' of conspirative connotations.

Keywords: hoaxes, fake news, Neo-fascism, propaganda, Slovakia, Central Europe, security politics, V4 countries.
\end{abstract}

\footnotetext{
${ }^{1}$ Associate professor, Department of Security Studies, Faculty of Political Science and International Relations, Matej Bel University, Banská Bystrica (Slovakia). Email: anton.hrubon@umb.sk

The paper is an output of VEGA project No. 1/0185/20 Mýtus a kult Slovenského štátu v historicko-spoločenskom diskurze po roku 1945: zrod, vývojové tendencie a odrazy v politickej kultúre [Myth and cult of the Slovak State in historical and social discourse after 1945 (birth, development trends and reflections in political culture)]
} 


\section{INTRODUCTION}

The notable rise of neo-fascist movements throughout Europe in the last decade has raised challenging questions for the academia and governments' security politics: if fascism's comeback in its 1930s-1940s stamina is unlikely, as many experts assert, why should the societies be aware of its temptations? What is the legitimacy of integrating the 'struggle against political extremism', which also includes neo-fascism, in almost every country's security doctrine? Though at the time of writing this article, the neo-fascist parties in all European countries have not been given the opportunity to gain a share of governmental power, their impact on internal politics and the general atmosphere is indisputable and immense.

Drawing on the contemporary paradigm of ongoing extensive international debates in the field of comparative fascist studies, the hypothesis of this case study is to argue that, although at the beginning of the 2020s the neo-fascist movements are, in general, relatively minor political force and, under current circumstances, have only a weak chance to become an acceptable governmental partner, their major current threat lies in a potential to radicalize the 'traditional' political movements via infiltration of fascist rhetoric into the 'mainstream' discourse, which may lead to fascistization of political culture and transformation of the social milieu in the affected country. This shift can eventually result in making of serious threats to internal security and political regime's status quo, e.g., cultural wars, ethnic, religious, or racial conflicts, exclusion of certain social communities accompanied by massive dehumanization campaigns, strengthening of antisystem forces, or, in the worst-case scenario, to a destruction of the existing order in the broadest sense of the word.

In his famous The Nature of Fascism, political theorist Roger Griffin stresses the role of mythic core the fascists have expressed in their political communication: a central narrative (or a set of narratives) around which they build up a specific 'world of truths' the fascists and fascists' followers believe in. Since the defeat of 'historical' fascism in 1945, the social-political environment in Europe has essentially changed. As fascism is, still, notwithstanding the country, generally considered a deadly ideology leading to genocides and a dangerous political force responsible for unprecedented terror and damages, the modern fascist (neo-fascist) political parties and organizations had to adapt to a new post-war or postsocialistic reality. They usually keep denying any relation to their older predecessors and nominally renounce the fascist identity. They have revised the style of political practice (dress code, social behaviour, etc.), 
stopped emphasising a violent revolution as an inevitable tool for 'spiritual regeneration' of a nation, creation of a palingenetic 'new society' and a 'new man'. Following the suggestions by Alain De Benoist, a prominent theorist of the Nouvelle Droite ('New Right'), whose conception has significantly influenced current neo-fascist movements' ideologies, many neo-fascists gave up trying to reach an impact comparable to that from the 'fascist era' by combining legal and illegal methods attempting for power takeover. Instead, they have started concentrating on conquering the political milieus via metapolitics (De Benoist and Champetier, 2012, p. 9) ${ }^{2}$ which, in other words, means nothing but a gradual step-by-step cultural fascistization of public discourse (see: Copsey, 2020).

One of the neo-fascists' key tools in meeting this goal is digital technologies. Nowadays, characterised by a high degree of societal internetization, the neo-fascists have discovered cyberspace as an ideal platform for a mass-scale distribution of hoaxes and fake news. ${ }^{3}$ Hoaxes and fake news have always been inherent features of fascism's nature, fascist movements' persuasive strategies and methods they profited on, seeking the aim to spread fear as a salient component of fascists' mobilization strategy and raising the political capital within society. Even though their expressions and communication contexts have mutated in the stream of time, the core of ideology remains principally intact.

Based on these groundings and the methodological framework, the article will try to provide an overview of the most frequent topics of neofascist hoaxes and fake news and analyse their political utilization on a

\footnotetext{
${ }^{2}$ The New Right's Manifesto states that 'metapolitics is not politics by other means... It rests solely on the premise that ideas play a fundamental role in collective consciousness... There is the growing impotence of political parties, unions, governments, classical forms of conquest and the exercise of political power... Metapolitical action attempts, beyond political divisions and through a new synthesis, to renew a transversal mode of thought and, ultimately, to study all areas of knowledge in order to propose a coherent worldview'. For a critical analysis of the New Right's intentions see: Griffin, 2000.

${ }^{3}$ The article perceives hoaxes as 'an act intended to trick or dupe; something accepted or established by fraud or fabrication' (Merriam-Webster, n.d.). Fake news may be defined as a type of hoax, misleading or false information presented as news. Fake news is usually spread by 'non-traditional' media (social media, conspiracy websites, etc.) with the intention to confuse the readers for the purpose of political and economic profit.
} 
model of the Slovak political milieu, laying an accent on their historical background, transformation, current semantics, and possible security threat they pose as factors of potential societal radicalization. For heuristic and analytic purposes of this article, the case study includes solely parties and movements reflected as openly neo-fascist according to Roger Griffin's and Cas Mudde's definitions distinguishing between fascist (neofascist) subjects on one hand, and far-right (radical/extreme right) on the other (Griffin, 1991, pp. 161-179; Griffin, 2018, pp. 91-125; Mudde, 2000, pp. 1-24). ${ }^{4}$

Neo-fascism in Slovakia has undergone a dynamic transformation after the 1989 fall of the communist regime in Czechoslovakia. The pioneer Slovak neo-fascist organizations might be divided into two groups.

The first emerged from admirers of the wartime Nazi-allied Slovak State (1939-1945) and its President, Catholic priest Jozef Tiso. These Lilliputian parties of almost zero relevance, like the National Council for Liberation of Slovakia (Národná rada za oslobodenie Slovenska), Movement for Liberation of Slovakia (Hnutie za oslobodenie Slovenska), Slovak National Unity (Slovenská národná jednota), or Slovak People's Party (Slovenská l'udová strana), which proclaimed itself a successor of the Slovak State's only allowed ruling party, were active during the period of Czecho-Slovak federation (1990-1992) and legitimized themselves by a 'struggle for Slovak independence'. In political practice, their activities and political language were framed by intolerant nationalism with strong anti-Czech and, partly, anti-Semitic sentiments, nostalgia for the wartime 'golden era', as they claimed, as well as by conspiracy theories spreading the fear of forces which, according to their rhetoric, wanted to 'rig Slovakia and the Slovak nation' (Rychlík, 2012, pp. 151-152). These minor parties, overshadowed in terms of widely supported

${ }^{4} \mathrm{~A}$ comprehensive overview of how to distinguish between the movements within the 'far-right family' is explained in detail by Nociar (2016) as well. It should be noticed that up to this day, the history and present of the post-1989 Slovak far right-right, neofascism and neo-Nazism have not been synthesized in a comprehensive monograph. Therefore, the researchers dispose only research papers cited in the following sections of this article and several analytical materials, e.g., Milo, 2004; Biháriová, 2012; analytical bulletins published by the Institute for Public Affairs (Inštitút pre verejné otázky - IVO; see: Mesežnikov and Gyarfášová, 2016; Bútorová et al., 2017), etc. 
nationalistic populism by the Slovak National Party (Slovenská národná strana), balanced on the edge between far-right and intellectual neo-fascism and, sooner or later, fell into utter insignificance.

The second line of Slovak post-1989 neo-fascism has been represented by various 'groupuscules' neo-Nazi organizations not involved in politics, which openly declared the racist worldview and were inspired by the global neo-Nazi subculture promoting Hitler's 'Third Reich', anti-Jewish conspiracy theories, anti-Blacks and anti-Roma hate speech, and the Holocaust denial.

In 1995, the Slovak Ministry of Interior registered Slovak Togetherness (Slovenská pospolitost), originally a nationalistic civic association which came into public's consciousness a decade later as the most notable and visible neo-fascist organization with a neo-Nazi background, transformed in 2005 into a political party (dissolved by the Supreme Court a year later). As proved by many authors (e.g., Budajová, 2018; Drábik, 2019; Vasil'ková and Androvičová, 2019), this 'founding mother' of Slovak political neo-fascists is ideologically and personally linked to as of 2020 active parliamentary movement People's Party Our Slovakia (L'udová strana Naše Slovensko), considered neo-fascist by academic and security experts. Prominent representatives (e.g., Marian Kotleba, Rastislav Schlosár) have been the leading figures of Slovak Togetherness during its most radical era; the others, including MPs, candidates and local party authorities (Milan Mazurek, Stanislav Mizík, Andrej Medvecký, Michal Buchta, Rastislav Rogel, Marián Mišún, Rastislav Jakubík, etc.), were accused of, and some of them also sentenced for extremist crimes (Benčík, 2019).

\section{FROM 'JUDEO-BOLSHEVISM' TO 'Z.O.G.' AND THE SOROS-RELATED OBSESSIONS}

One of the most used hoaxes of the modern age in public discourse has been a 'Jewish plan for global domination'. This myth, rooting in the new wave of rising anti-Semitism at the turn of the $19^{\text {th }}$ and $20^{\text {th }}$ centuries has been reflected in almost all European political cultures. Publication of the

\footnotetext{
${ }^{5}$ Official names of the party have changed during its existence as follows: February 2010 - November 2015 L'udová strana Naše Slovensko, November 2015 - November 2019 Kotleba - L'udová strana Naše Slovensko, since November 2019 Kotlebovci - L'udová strana Naše Slovensko. To simplify and not confuse the reader, the article operates solely with the name L'udová strana Naše Slovensko.
} 
notoriously known Protocols of the Elders of the Zion (1903), fabricated by the Russian emperor police, strengthened the conspiracy perception of Jews as an 'alien' community, caused rising hostility and radicalization of the majority resulting in anti-Jewish pogroms and the 'expulsion' of them from nations across the continent. Later the hoax was instrumentalized by the fascists after 1919. Struggle against 'Judeo-Bolshevism', a construct referring to the paranoid merge of Jews with Bolshevism, became a 'security doctrine' of various far-right, fascist and Nazi-allied government, including the wartime Slovak State's (1939-1945) Miklós Horthy's regime in Hungary (1920-1944) or interwar Poland: anti-Jewish spirit and subsequent antiJewish measures were justified by the inevitable elimination of both Jews and Bolshevism from public life as noted 'eternal foes' and a 'threat' to European civilization and Christian culture. Not even the memento of the Holocaust, which the neo-fascists deny or flout, has silenced the voices suspecting the Jews of world domination intentions (Hanebrink, 2018).

In Slovakia, apart from marginal far-right movements founded after 1989 and the neo-Nazi subcultures, anti-Semitic hoaxes and fake news containing the 'Jewish aspect' were represented to the greatest extent by Marian Kotleba's Slovak Togetherness mentioned above. Slovak Togetherness, expressing its deepest sympathies to the wartime Hlinka's Slovak People's Party's regime with fascist tendencies, had frequently been thematizing the historically rooted archetype of a Jew controlling the world economy and national governments attempting to create and retain the 'New World Order' (NWO). All the cabinets after Slovakia's accession to the EU were marked as 'Zionist Occupation Government' (ZOG) in Kotleba's speeches and the organization's periodical called Prúty ('Rods'). The anti-Semitic spirit of Kotleba's propaganda did not vanish from his newspapers even after he was elected the Governor of Banská Bystrica Region in 2013. Bimonthly magazine Náš kraj ('Our Region') published in one of its 2015 issues a cartoon of a crossed giggling Jew with a bundle of banknotes in his hand, stating that the region's administration under Kotleba's leadership was 'liberating the region of debt slavery' (Poláš, 2015).

After Kotleba's People's Party Our Slovakia (L'udová strana naše Slovensko - LSNS) entered the National Council of the Slovak Republic in 2016, its MPs, including Kotleba, have started to hide or deny their anti-Semitism in contrast to the era of Kotleba's involvement in the Slovak Togetherness (Cirner and Dudinská, 2020, p. 185) and to proclaim it in various metaphorical cultural codes instead, which on one hand do not conflict with the law but, on the other hand, lucidly express a clear message to the party's 
supporters as well as the broader public. Kotleba and his PR managers figured out that an open fierce anti-Semitism is, in general, not popular among the Slovak society. However, in its masked forms, especially in combination with the modernist expressions and associations criticizing the world geopolitics and Western civilization supposedly controlled by the 'Zionist lobby', economically motivated frauds historically linked in conspiracy discourse with the Jews, and with the role of 'foreign factors', 'corrupted' and 'anti-national' NGOs on domestic politics, the potential of society's radicalization by this conspiratorial image of world's functioning is not negligible. All the more, when it is being adopted by traditional and democratic parties that declare their principled anti-fascist stance.

Adoption and usage of originally neo-fascist anti-Semitic hoaxes have intensified in Slovak political culture following the murder of investigative journalist Ján Kuciak and his fiancée in February 2018. The ruling socialdemocratic party SMER-SD headed by Robert Fico had already been associated with corruption scandals, interconnections between the government, police, jurisdiction and ill-reputed business circles close to the mafia to which the traces of suspicion of a murder order led for a while at that time. The accumulated atmosphere within the society eventually erupted into the most extensive anti-governmental protests since 1989 supported by a critique of President Andrej Kiska.

As the crisis between President and the government had been escalating, in March 2018, Fico, whose cabinet faced a threat of collapse and - in case of new general elections - criminal prosecution of its members as well, reached out for irrational counterattack and instead of an acceptable response, accused Kiska of maintaining private contacts with George Soros. During his press conference, Fico asked: 'Today, at this press conference, I want to ask Mr President a simple question: 20 September 2017, New York, $5^{\text {th }}$ Avenue. I am asking, why the head of the Slovak Republic visited a private soil of a man whose name has a dubious reputation. And this man's name is Mr Soros' (Kern, 2018).

Sheltered by an argument of suspected 'foreign intervention' into internal Slovak affairs, Fico claimed that recent domestic events (president's, NGOs' and media's critique, upcoming planned anti-governmental protest) pursued a single intention - to totally destabilize the situation and prepare a fertile ground for overthrowing the government. After the media had informed that several tens of thousands of people were planning to attend the protests, Fico supported his previous reaction by alleged police findings, warning that the attacks on public buildings which were supposed to be 
executed by stone cubes found near the Governmental Office hidden in the bushes were highly probable.

Even though these rumours turned out fake (Ako Fico vydal, 2018), Fico's newspeak meant a crucial turnover in his profiling. By adopting a conspiracy, lucidly anti-Semitically motivated construct - regardless of him really believing it or not - Fico's and his party's reputation significantly changed in the eyes of the conspiracy scene and neo-fascists. A politician who was, together with his minister of interior Robert Kaliňák, years ago labelled by Kotleba as a 'representative of a police state' due to 'brutality against the nationalists', received shortly after his summer 2020 political comeback a proposal from the neo-fascist leader to 'unite the forces' in joint actions against the new government of Igor Matovič, blamed for 'killing the economy' and 'anti-democratic measures' introduced during the second Covid wave in November 2020 (Priaznivci kotlebovcov, 2020).

Except galvanizing the 'Soros-myth' in 2018, the anti-Semitic framework as a mobilizing stimulus resonated again during a campaign before the presidential election held in March 2019. Presidential candidate Zuzana Čaputová had not been accused by her opponents only of being a 'pawn of neoliberalism' and her campaign being co-financed directly by George Soros, but also of Jewish descent. To highlight this fake news, the magazine Zem a Vek ('Earth and Age'), very popular among the conspirators and neofascists, photoshopped Čaputová's picture in an unprecedented way: a modified image published online, accessible to anyone just several days prior to the second decisive round, portrayed Čaputová with a crooked nose and fleshier lips, intending to underline her 'Jewishness' (Šnídl, 2019). The photomontage's aim was not only to revive subconscious anti-Semitic sentiment of part of the voters (which might have influenced a group of the undecided) and to fuse the conspirators' as well as neo-fascists' negative associations of liberalism, 'Jewish world domination', 'éminence grise' standing behind the electoral curtain and 'threat of a woman rule' into a unifying 'mosaic of evil', but also, taking the broader sociopolitical context into consideration, to indirectly help Maroš Šefčovič, Čaputová's countercandidate supported by Fico's SMER-SD.

Despite efforts to discredit both Andrej Kiska and Zuzana Čaputová through anti-Semitically motivated connotations previously used in postsocialist Slovakia's relevant political discourse almost solely by the neofascists, the strategy did not prevail. According to opinion polls on politicians' credibility from April 2018, even after the crisis between the President and Prime Minister, Andrej Kiska held his position of the most 
trusted politician $(46.2 \%)$ while Fico dropped to seventh place $(23.1 \%)$ (Dôveryhodnost' politikov, 2018). Even the attempts to stigmatize Čaputová as a 'Soros-deployed agent' of 'Jewish origin' proved counterproductive: Čaputová defeated Šefčovič in $58.40 \%$ to $41.59 \%$ ratio and won in many municipalities where Šefčovič or Kotleba celebrated a first-round victory (Vol'by prezidenta Slovenskej republiky, n.d.). ${ }^{6}$

In general, anti-Semitic framed hoaxes and fake news have shown their minimal potential to become a functional tool in political campaigns in contemporary Slovakia. Though anti-Semitism had been one of the core elements of the wartime Third Reich's collaborating Slovak State's regime, it has not disappeared completely from the Slovak political culture and, from time to time, has still been used by political subjects/politicians (including some of the 'mainstream' parties) as the 'last lever', it significantly lacks broader legitimacy: according to the 2011 census, the number of Jews in Slovakia has decreased below 2.000 (Obyvatel'stvo SR podl'a náboženského vyznania, n.d.), none of the foremost Slovak politicians admits his/her Jewish origin or identity, and the public discourse misses a self-proclaimed Jewish-associated 'éminence grise' with a noticeable impact on internal Slovak politics. Even the leader of governmental 'We are family' (Sme rodina) movement Boris Kollár, a successful businessman who openly admitted several of his racially persecuted family members had died in concentration camps, has not been confronted with his Jewish roots by the opposition so far. In this context it should be noted that in May 2019 Kollár hosted an Identity and Democracy Party's session in Bratislava, attended by Marine Le Pen and Matteo Salvini, and held an energetic speech in Italian at Salvini's Lega Nord Milanese gathering shortly after (Boris Kollár, 2019).

\section{'THE GYPSY PROBLEM'}

The question of 'socialization' of the Roma population has been resonating in Central Europe for more than a century. Even after the transformation of the Roma's way of life from nomadic to settled, completed by the communist regimes, the 'Roma question' in the broadest sense remains a big challenge for governments. The Roma's 'otherness' and negative connotations (cultural, social, racial) historically attributed to them by the majority have provided the neo-fascist movements a 'punching bag'

${ }^{6}$ Marian Kotleba ended up in fourth place in the first round with $10.39 \%$ and did not advance to the second round. 
usable in venting their radicalism. Unlike the abstract 'Jewish threat', the propaganda image of a 'dirty Gypsy' who 'parasites on the social system', 'refuses to work' and to 'socially adapt', has achieved notable response within the relatively broader audience of neo-fascist as well as right-wing nationalist and populist parties.

This generalized image became one of the core topics in Slovak Togetherness' discourse immediately after its establishment. Togetherness had been promoting the idea of 'some form of isolation of Gypsies'; however, despite the hoaxes expressing the 'threat' that the Roma people 'will roll over the Slovak nation' (Vražda, 2020, pp. 21, 27) were present in organization's rhetoric, they did not dominate at Togetherness' beginnings and only coshaped the conspiratorial puzzle made of anti-American (anti-NATO), antiEU and, most of all, anti-Hungarian segments.

However, in November 2008, the members of Togetherness visited a rally of their partner Czech organization called the Workers' Party (Dèlnická strana - DS), after its 2010 ban transformed into the Workers' Party of Social Justice (Dělnická strana sociální spravedlnosti - DSSS; see: Dlouhý et al., 2020).? Slovak journalist Daniel Vražda considers Kotleba's presence at the Litvínov protests, during which the neo-fascist radicals accompanied by local citizens tried to get into the police-protected Roma ghetto of Janov, a turning point in his strategy. The slogan 'to protect the whites from the Gypsies' and 'the polite people from the anti-socials' (Vražda, 2020, p. 51) soon turned into the most powerful weapon of the neo-fascist propaganda on which this spectrum has been capitalizing until nowadays.

Putting the emphasis on 'solving the Roma question' earned Kotleba popularity incomparable with that before, when his and Togetherness' communication was characteristic of spreading hoaxes and fake news on very 'distant' issues for Slovak voters (e.g., American geopolitics, Zionism, etc.) or issues which they did not perceive as an immediate threat (e.g., Hungarian revisionism). By a constant accentuation of the 'Gypsy problem', Kotleba acquired a coveted fulcrum of his targeted propaganda. From 2009, a year before the general election, he started a state wide 'mobilization', travelling region to region where the interethnic problems between the majority and the Roma population had occurred in the past, supported by a clearly DS-inspired poster campaign portraying a laughing tattooed Roma

\footnotetext{
${ }^{7}$ For the historical background of Czech neofascism see: Mareš, 2003.
} 
encircled by children with a text saying 'Look how they are laughing! Thanks to our taxes! Do you want to change it? Come, vote Kotleba!' (Vražda, 2020, p. 52).

As Kotleba's electoral support had been slightly growing (despite still being on the margin of the political scene with less than $2 \%$ ), the traditional Slovak National Party (Slovenská národná strana - SNS) borrowed his antiRoma rhetoric in the 2010 election campaign and misused an image of a corpulent Roma with the following slogan '... So that we will not feed those who do not want to work' on the party's billboards all over Slovakia (Kováčová, 2010). Although the SNS's chair Ján Slota had previously caused many controversies with his sharp anti-Hungarian and partly anti-Roma discourse, it was the first time when a Slovak pro-European party, stressing its democratic character and values, adopted open racism representing the political subject as such, not only the leader's private opinion. The 2010 general elections showed how the populist party facing the failure of nonmeeting the quorum (SNS eventually gained only $0.07 \%$ more than the necessary $5 \%$ ) was capable of taking unexpected steps beyond its official ideological framework just to get into the parliament (Počet a podiel, 2010).

Although the Slovak National Party's temporal tactics to use the racist propaganda was not expected, in the context of its leaders' previous hate speech, it did not surprise anyone. What the public shocked much more was Robert Fico's and Robert Kaliňák's shift to 'politics of order' during SMER-SD's last rule (2016-2020), clearly motivated by the success of Kotleba's strategy of anti-Romani framed PR. Despite Fico had already addressed voters with an anti-Roma agenda wrapped in a package of social populism years ago (Bariak, 2020), after SMER-SD came to power as the winner of the 2006 general elections, Fico's criticism on the Romani had muted and many Roma voters were considered his followers. Right after a series of setbacks, including Vladimír Maňka's (a SMER-SD nominee's) loss in the 2013 county election to Marian Kotleba and following Kotleba's People's Party Our Slovakia's premiere election to parliament in 2016, Fico started promising he, along with his Minister of Interior Kaliňák, would 'restore an order', support the police in its crackdowns in the Romani settlements and stop the Roma 'misusing the social system in Slovakia' (Tódová, 2016).

SMER-SD's anti-Romani discourse strengthened after the party failed in the 2020 general elections and became an opposition alongside Kotleba's LSNS. Following Robert Fico's vlog defence of Kotleba's MP Milan Mazurek sentenced in September 2019 to a $€ 10.000$ fine for racial hatred in a radio broadcast ('Milan Mazurek just said what almost the whole nation thinks') (Fico, 
2019), he stated that the new Prime Minister Igor Matovič is ' $a$ Prime Minister of the Roma, of the Gypsies; he does not care for anyone else' (Mikušovič, 2020). Reaction on Matovič's aid provided to the Romani in eastern Slovakia, whose settlement had to be quarantined under the military and police supervision due to a massive incidence of coronavirus in the first Covid wave, suggests not only the validity of premise raised above, that in times of movement's existential crisis even the democratic and anti-fascist profiled political parties are not immune to taking on the (neo)fascist conspiracies and hoaxes, as well as that Kotleba's repeated success and his 'from zero to hero' rise radicalized the political discourse in Slovakia and 'mainstreamized' a political communication previously typical for nondemocratic regimes or, as Viktor Orbán said, for 'illiberal democracies'.

\section{'MUSLIM AND AFRICAN AVALANCHE THREATENING CHRISTIAN AND EUROPEAN CIVILIZATION'}

Since the end of World War II, the ethnic structure of Europe has fundamentally changed (see Bade, 2005; Hruboň et al., 2017; Ther, 2014). Variously motivated massive migration flows and the state administration's 'incapability' of ceasing them have always been a matter of neo-fascists' ruthless criticism. A declared will to 'protect Europe', to 'defend Christian values', and to 'save cultural Western civilization' from being 'exploited' and 'raped' by the 'hordes from the East' has persisted in the fascist political language for decades: using the same expressions, Adolf Hitler and his Axis allies warned against the Soviet invasion of Europe in the 1930s and 1940s; now, the neo-fascists are using the same vocabulary for commenting the latest European migrant crisis.

Hoaxes and fake news distributed in this regard have comprised of two key dimensions:

The first might be understood as a modernist reincarnation of the conflict between the 'Christian' and 'Muslim' world, however, in its secularized cultural meaning cleaned of religious aspects. In Central European radicals' discourse (mainly in Slovakia and Hungary), the 'Muslim comeback' is frequently compared to the Ottoman occupation of the historical Hungarian Kingdom from the 1526 Battle of Mohács to the late $17^{\text {th }}$ century. The neo-fascists struggling against - as their discourse emphasises - the 'new occupation' often portray themselves as 'new-age knights' of noble intentions aiming to secure an 'eternal triumph' in the 'modern Reconquista' and to 'bring Europe back to its 
roots'. Refugees from the East (Syria, Afghanistan, Iraq) pouring into Europe are collectively being labelled potential 'terrorists', 'Islamic fundamentalists', 'jihadists' and 'severe threat to national security'; the migrants from Africa as 'unwelcome persons', 'burden to the social system', 'unable and unwilling to work'. The neo-fascists thus perceive combatting the migration flow as a self-preservation campaign and, in a biological sense of the word, as the white supremacy theorist Ben Klaasen prophesied RAHOWA ('Racial Holy War'). In this context, the neo-fascists' reactions to the migrant crisis and their reflection in the disseminated hoaxes and fake news cannot be seen just as religious conflict, 'some kind of war of identities' which are always irreconcilable, radical, and fundamentalist (Kazanský, 2013, p. 68), but also as a war between 'cultural West' and 'decadent East' with the hidden racial and eugenic core.

The second dimension of the neo-fascist hoaxes and fake news related to the migrant crisis lies in their anti-system framework allegorically opposing liberal democracy. In this case, the neo-fascists have been blaming not just the migrants but also Western politicians, intellectuals, media, NGOs, and other specific social groups for the intentional undermining of Western culture by promoting the idea of multicultural humanistic Europe and open society. In a conspiratorial discourse, the European migrant crisis, during which millions of refugees fled to Europe, was artificially provoked as a part of a plan developed by the 'cultural Marxists' to put Western culture to its knees and raise a new mixed shapeless and nameless society. Cultural Marxism conspiracy theory has gained many supporters, including Nazi-inspired terrorist Anders Behring Breivik, who perceived his 2011 Utøya attacks as an assault on cultural-Marxist values represented by the leftist governments in Norway and Europe enabling the destruction of 'true European values and identity' (Jarmin, 2014, p. 85).

It should be noted that despite the neo-fascists in Central Europe shared the same anti-migrant stance as their comrades in other countries, commenting on the migrant crisis did not markedly differ from the governmental rhetoric as well as political and security measures taken in its spirit. Fico's government - contrary to President Andrej Kiska's emphatic words (Kiska, 2015) - categorically rejected the principle of 'joint responsibility' of all EU member states promoted by German or French authorities to adopt a common security politics in terms of immigration management. Hungarian Prime Minister Viktor Orbán took a protectionist 
attitude too: he ordered to build a $175 \mathrm{~km}$ long barbed-wire fence on the border with Serbia and a $40 \mathrm{~km}$ long one on the border with Croatia. ${ }^{8}$

In the summer of 2015, three of four V4 countries - Slovakia, Hungary, and the Czech Republic supported by Romania - announced that none of them would ever accept any long-term EU-issued quota of accommodating the migrants as requested by German Chancellor Angela Merkel (V4 sa dohodla, 2015). This uncompromising attitude, the legitimacy of which in the eyes of the public was confirmed by the 2015 Charlie Hebdo shootings and subsequent November attacks at multiple places in Paris, silenced the neo-fascists' criticism of governments in Central Europe, and forced them to redirect the fury of foreign officials who had been emphasising the need for solidarity with the refugees.

\section{GENERIC HOAXES AND FAKE NEWS AS ANTI-SYSTEM LANDMINES OR WHAT IS THE NEO-FASCISTS' PURPOSE OF BEING PERSISTENTLY RESISTANT (CONCLUDING REMARKS)}

Conspiracy thinking (see: Panczová, 2017) has been a core feature of fascist ideology ever since its inception. Fascist deep persuasion that complicated the modern world around us is influenced and controlled by the 'dark forces' who use corrupted puppet governments to reach their global domination and destruct the 'genuine European values' was principally the same both in 1933 and 2020. However, what has essentially changed, is the methods the fascists (neo-fascists) use to decompose the detested democratic system. The romantic era of coups d'état and demonstrative 'marches on Romes' seems to be long gone. The neo-fascists know very well what their historical predecessors committed - and, therefore, are ashamed to openly subscribe to fascist ideology. The neofascists have not transformed only the external visible elements of political culture and behaviour ('from uniforms into suits strategy') but also the strategies of 'conquering the system' (see: Drábik, 2019, pp. 468-561).

\footnotetext{
${ }^{8}$ Hungarian Prime Minister Viktor Orbán declared, regarding the reception given to migrants, that: 'It must not be forgotten that those who are arriving... are the representatives of a profoundly different culture. For the most part, they are not Christians but Muslims. That is an important question because Europe and European identity have Christian roots'. (Camus and Lebourg, 2017, p. 287).
} 
In the last decades characterised by a mass dispersion of new communication technologies, the neo-fascists took their chance to rise again, this time differently and much more sophisticated than after 1945. The climax we are witnessing now in Slovakia, as well as in Central Europe, is a hybrid cultural war between liberal democracy as a system (not ideology) that became mainstream following the downfall of the communist regimes and (neo) fascism with its alternative anti-utopian vision of the world. The neo-fascist movements' potential cannot be underestimated: even as of 2020, the neo-fascists have not embodied a security threat in terms of possible violent power takeover or parliamentary election victory, their diversionary ideological war has significantly impacted the political milieus, as this article has proved on several examples. Systematic and long-lasting communication with their followers via the internet (in Central Europe mainly on conspiratorial websites, various internet forums, Facebook, and Russian 'VKontakte' platform) has not been mirrored only in a relatively stable electoral support to People's Party Our Slovakia or Hungarian Jobbik and a consolidation of their position in the structure of well-established parties, but also in making of a new, still dynamically forming social group of anti-system radical nihilists.

Hoaxes and fake news spread individually in reaction to current events, sometimes also by the mainstream media, are not more dangerous from the perspective of society's radicalization than ordinary rumours or whispering campaign: they appear and then fade over time, replaced by fresher ones. However, in recent years we may observe that thanks to social networks in Central Europe Facebook in particular - the rooted hoaxes and fake news promoted and/or produced by the neo-fascist movements have in their interconnectedness mutated into a comprehensive ideology within which all partial units of discourse $(9 / 11$, chemtrails, medical misinformation including the anti-vaxxer movement as well as the hoaxes and fake news based on conspiracy theories above) merged into a compact worldview which identifies itself as anti-system, anti-establishment and exclusively true.

Metaphorically speaking, accumulated hoaxes and fake news, spreading uncontrollably and super fast, have turned into a chain of landmines and seriously threaten the democratic system. The neo-fascists have successfully penetrated the public discourse masking their palingenetic radicalism by 'freedom of speech' and hiding behind the right to let anyone 'express an opinion'. The chameleon-like transformation has made the neo-fascists more refined. Their fascist identity (which the neo-fascists question) remains cocooned for a lay audience because of 'mainstreamization of fascism' 
(Kallis, 2013), difficult to distinguish from radical (extreme) non-fascist right and, as neo-fascists' influence on traditional parties point out, also from 'standard' parties. In doing so, the difference between far-right and neofascist organizations from the point of view of democratic system's stability is crucial: whilst the 'standard' parties including far-right want only to take control over institutions, the neo-fascists seek to knock the existing order down and to build up a new dystopian society ('new nation', 'new man', etc.), even though, in the modern times, they resigned to impatience in creating the desired revolutionary 'new order' and, instead, bet on the strategy of gradual metapolitical fascistization.

In this regard, both Slovakia and Central Europe provide unique examples of how modern fascism has lost nothing of its strength, despite its limited manoeuvring possibilities. Without any doubts, People's Party Our Slovakia and Jobbik belong to the most successful metapolitical projects in Europe and, at least, Kotleba's movement's share of governmental power cannot be ruled out in a medium-term future: moving away from an openly neo-Nazi subculture (accompanied at that time by marching through streets in dark uniforms with burning torches and praising Jozef Tiso's wartime Hitler's allied Slovak State), its continuous tactical shift to far-right acceptable for a broader audience, and electoral support climbing up to double-digit numbers, make Kotleba's party an attractive partner for a hypothetically strong 'illiberal coalition'. Evolution of hoaxes and fake news in the Slovak milieu, which make up a core of the People's Party Our Slovakia's political agenda and PR, as well as their perception in politics and by the broader public, thus remains barely predictable.

\section{REFERENCES}

Ako Fico vydal falošné varovanie vo vypätej situácii: Z kôp kociek sa nakoniec stala fraška [How Fico issued a false warning in tense situation: The piles of cubes eventually became a farce]. (2018, December 31), retrieved from https:/ / slovensko.hnonline.sk/1862304-ako-fico-vydalfalosne-varovanie-vo-vypatej-situacii-z-kop-kociek-sa-nakoniec-stalafraska. Accessed 8 January 2021.

Bade, K. (2005). Evropa v pohybu: evropské migrace dvou století Europe on the move: [European migration of two centuries]. Praha, Nakladatelství Lidové noviny.

Bariak, L. (2020, May 6). Fico sa vracia do politickej minulosti. Na Rómov útočí slovníkom extrémistov [Fico returns to politics and attacks the 
Roma by extremists' language], retrieved from https:/ /www.aktuality. sk/clanok/788225/fico-sa-vracia-do-politickej-minulosti-na-romovutoci-slovnikom-extremistov/. Accessed 8 January 2021.

Benčík, J. (2019, December 19). Kotlebovské esá, klamstvá a burcovanie vášní [Kotleba's aces, lies and excitement of passions], retrieved from https:/ / dennikn.sk/blog/1686686/kotlebovske-esa-klamstva-a-burcovanievasni/. Accessed 10 January 2021.

Biháriová, I. (2012). Vývoj pravicového extrémizmu na Slovensku v rokoch 19892012 [Development of right-wing extremism in Slovakia 1989-2012]. Bratislava, Friedrich Ebert Stiftung.

Boris Kollár sa v Miláne zúčastnil na zhromaždení krajne pravicových síl. Velebil Salviniho [Boris Kollár took part in gathering of the far-right forces in Milan. He praised Salvini]. (2019, May 18), retrieved from https://hnonline.sk/eurovolby-2019/clanky/1943517-boris-kollar-sav-milane-zucastnil-na-zhromazdeni-krajne-pravicovych-stran-velebilsalviniho. Accessed 8 January 2021.

Budajová, M. (2018). Programatika a ideológia Ĺudovej strany Naše Slovensko a Slovenskej pospolitosti - národnej strany [Programmes and ideology of the People's Party of Our Slovakia and the Slovak Commonwealth - the National Party], Politologická reoue, 24(1), pp. 89-121.

Bútorová, Z., Gyárfášová, O., Mesežnikov, G. \& Velšic M. (2017). Zaostrené na extrémizmus : Výskumná štúdia [Focused on extremism : Research study]. Bratislava, Inštitút pre verejné otázky.

Camus, J.Y. \& Lebourg, N. (2017). Far-Right Politics in Europe. Cambridge \& London, The Belknap Press of Harvard University Press.

Cirner, M. \& Dudinská, I. (2020). The entry of an extreme right party into the Slovak parliament after the 2016 and 2020 elections: The return of fascists?, Balkan Social Sciences Review, 16, pp. 175-197.

Copsey, N. (2020). Neo-Fascism: A Footnote to the Fascist Epoch?, in: C. Iordachi \& A. Kallis (Eds.), Beyond the Fascist Century: Essays in Honour of Roger Griffin (pp. 101-121). Basingstoke, Palgrave Macmillan.

De Benoist, A. \& Champetier, C. (2012). Manifesto for a European Renaissance. London, Arktos.

Dlouhý, M., Háka, A. \& Rataj, J. (2020). Proti systému! Český radikální konzervativizmus, fašismus a nacionální socialismus 20. a 21. Století [Against the system! Czech radical conservatism, fascism and national socialism of the 20th and 21st centuries]. Praha, Auditorium. 
Dôveryhodnost' politikov podl'a agentúry FOCUS [Credibility of politicians according to the FOCUS agency]. (2018, April 24-30), retrieved from https://volby.sme.sk/pref/2/doveryhodnost/p/focus/2018-05-10. Accessed 8 January 2021.

Drábik, J. (2019). Fašizmus [Fascism]. Bratislava, Premedia.

Fico: Mazurek povedal to, čo si myslí takmer celý národ, Kotlebovi budú preferencie utešene rást' [Fico: Mazurek just said what almost whole nation thinks, Kotleba's support will rapidly rise]. (2019, September 5), retrieved from https://slovensko.hnonline.sk/2001387-fico-mazurekpovedal-to-co-si-mysli-takmer-cely-narod-kotlebovi-budu-preferencieutesene-rast. Accessed 8 January 2021.

Griffin, R. (1991). The Nature of Fascism. London, Pinter.

Griffin, R. (2000). Between metapolitics and apoliteía: the New Right's strategy for conserving the fascist vision in the 'interregnum', Modern and Contemporary France, 8(1), pp. 35-53.

Griffin, R. (2018). Fascism: An Introduction to Comparative Fascist Studies. Cambridge, Polity Press.

Hanebrink, P. (2018). A Specter Haunting Europe. The Myth of Judeo-Bolshevism. Cambridge \& London, The Belknap Press of Harvard University Press.

Hruboň, A., Šmigel', M. \& Pecníková, J. (2017). Migračné pohyby z krajín a medzi krajinami V4 v historickej perspektíve (Vybrané problémy) [Migration movements from and between the V4 countries in a historical perspective (Selected issues)]. Banská Bystrica, Belianum.

Jarmin, J. (2014). Cultural Marxism and the Radical Right, in: P. Jackson \& A. Shekhovtsov (Eds.), The Post-War Anglo-American Far Right: A Special Relationship of Hate (pp. 84-103). Basingstoke, Pagrave Macmillan.

Kallis, A. (2013). Far-Right "Contagion" or a Failing "Mainstream"? How Dangerous Ideas Cross Borders and Blur Boundaries, Democracy and Security, 9(3), pp. 221-246.

Kazanský, R. (2013). Súčasné problémy výskumu medzinárodných konfliktov a kríz a ich riešenia [Current problems of research of international conflicts and crises and their solutions]. Banská Bystrica, Vydavatel'stvo UMB Belianum.

Kern, M. (2018, March 5). Fico vidí za tlakom na Kaliňáka pokus o prevrat a Sorosa [Behind the pressure on Kaliňák, Fico sees a coup attempt and Soros], retrieved from https:// dennikn.sk/1050737/ fico-vidi-za-tlakomna-kalinaka-pokus-o-prevrat-a-sorosa/. Accessed 8 January 2021. 
Kiska: Prijatie utečencov bezpečnost' Slovenska a jeho hodnoty neohrozí [Kiska: Hosting the refugees will not threaten the security nor the values of Slovakia]. (2015, September 7), retrieved from https:/ / spravy.pravda. sk/domace/clanok/366862-kiska-prijatie-utecencov-bezpecnostslovenska-a-jeho-hodnoty-neohrozi/. Accessed 8 January 2021.

Kováčová, M. (2010, May 5). SNS láka voličov na rasizmus [The Slovak National Party lures voters by racism], retrieved from https:// domov.sme.sk/c/5360060/ sns-laka-volicov-na-rasizmus.html. Accessed 8 January 2021.

Mareš, M. (2003). Pravicový extremismus a radikalismus v ČR [Right-wing extremism and radicalism in the Czech Republic]. Brno, Barrister \& Principal.

Merriam-Webster. (n.d.). Hoax, retrieved from https://www.merriamwebster.com/dictionary/hoax. Accessed 6 February 2021.

Mikušovič, D. (2020, April 30). Fico na d'alšej tlačovke bez Pellegriniho: Chcem viest' Smer s jasným pohl'adom na vec, nedovolím prejavy slniečkarstva [Fico at another press conference without Pellegrini: I want to lead SMER with a clear view on the issues and will not allow any manifestations of ultraliberalism in the party], retrieved from https://dennikn.sk/1877228/fico-na-dalsej-tlacovke-bez-pellegrinihochcem-viest-smer-s-jasnym-pohladom-na-vec-nedovolim-prejavyslnieckarstva/?ref=in. Accessed 8 January 2021.

Milo, D. (2004). Rasistický extrémizmus v Slovenskej Republike [Racist extremism in the Slovak Republic]. Bratislava, L'udia proti rasizmu.

Mesežnikov, G., Gyarfášová, O. Súčasný pravicový extrémizmus a ultranacionalizmus na Slovensku. Stav, trendy, podpora. Bratislava: Inštitút pre verejné otázky - Nadácia Hannsa Seidela, 2016.

Mudde, C. (2000). The ideology of extreme right. Manchester \& New York, Manchester University Press.

Nociar, T. (2016). Politológov sprievodca "terminologickým chaosom": Terminológia, charakteristika a konceptualizácia krajne pravicovej ideologicke0j rodiny [Political Scientist's Guide to “Terminological Chaos": Terminology, Characteristics and Conceptualization of the Far Right Ideological Family], Rexter - časopis pro výzkum radikalismu, extremismu a terorismu, 14(1), pp. 44-91.

Obyvatel'stvo SR podl'a náboženského vyznania - sčítanie 2011, 2001, 1991 [Population of the Slovak Republic by Religion - 2011, 2001, 1991 Census]. (n.d), retrieved from https:/ /www7.statistics.sk/wps/wcm/ connect/54eb0cba-ec99-4549-8a33-5c86eead59c1/Tab_14_Obyvatelstvo 
_SR_podla_nabozenskeho_vyznania_scitanie_2011_2001_1991.pdf?MO $\mathrm{D}=\mathrm{AJPERES}$. Accessed 8 January 2021.

Panczová, Z. (2017). Konšpiračné teórie: témy, historické kontexty a argumentačné stratégie [Conspiracy theories: topics, historical contexts and argumentation strategies]. Bratislava, VEDA.

Počet a podiel platných hlasov odovzdaných pre politické strany - Vol'by NR SR [Number and share of valid votes delivered to political parties General Elections]. (2010, June 13), retrieved from https://volby. statistics.sk/nrsr/nrsr2010/sr/tab3.jsp@lang=sk.htm. Accessed 8 January 2021.

Poláš, M. (2015, July 31). Kotleba má v župných novinách obrázok z antisemitskej karikatúry [Kotleba published a picture from the antiSemitic cartoon in the regional newspaper], retrieved from https:/ / medialne.trend.sk/ tlac/kotleba-ma-zupnych-novinachobrazok-antisemitskej-karikatury. Accessed 8 January 2021.

Priaznivci kotlebovcov protestovali pred Matovičovým domom [Supporters of Kotleba protested in front of Matovič's house]. (2020, November 28), retrieved from https://domov.sme.sk/c/22544328/pred-matovicovym -domov-sa-zisli-stovky-ludi.html. Accessed 8 January 2021.

Rychlík, J. (2012). Rozdělení Československa 1989 - 1992. Praha, Vyšehrad.

Šnídl, V. (2019, March 31). Blaha a d’alší konšpirátori sa snažili márne, Caputovej prvenstvo neohrozili [Blaha's and other conspirators' attempts proved fruitless, Čaputová's triumph not threatened], retrieved from https:/ / dennikn.sk/1427672/antikampan-2019-caputova-ustalablahove-konspiracie-aj-utoky-dezinformacnych-webov/. Accessed 8 January 2021.

Ther, P. (2014). The dark side of nation states: ethnic cleansing in modern Europe. New York \& Oxford, Berghan.

Tódová, M. (2016, December 10). Kaliňák dostal na sneme Smeru 318 hlasov, nový nepriatel' sú Rómovia [Kaliňák gained 318 votes on SMER's assembly, the Roma are a new enemy], retrieved from https:// dennikn.sk/630572/kalinak-dostal-na-sneme-smeru-318hlasov-novy-nepriatel-su-romovia/?ref=in. Accessed 8 January 2021.

Vasil'ková, A. \& Androvičová, J. (2019). Príčiny nárastu podpory pravicového radikalizmu a extrémizmu na Slovensku: príklad politickej strany Kotleba-L'SNS [Reasons for the increase in support for right-wing radicalism and extremism in Slovakia: the example of the political party Kotleba-L'SNS], Central European Journal of Politics, 5(1), pp. 71-99. 
Vol'by prezidenta Slovenskej republiky - 2. kolo [The President of the Slovak Republic Elections - Round 2], (n.d.), retrieved from https://volby. statistics.sk/prez/prez2019/sk/data03.html. Accessed 8 January 2021. Vražda, D. (2020). Kotleba. Bratislava, NPress.

V4 sa dohodla na spoločnom odmietnutí kvót pre migrantov [V4 agreed on joint refusal of the migrant quotas]. (2015, June 23), retrieved from https://www.vlada.gov.sk//v4-sa-dohodla-na-spolocnom-odmietnutikvot-pre-migrantov/. Accessed 8 January 2021. 